\title{
Analysis of the Effect of Product Quality, Price Perception and Social Value on Purchase Decisions for Lampung Tapis Fabrics
}

\author{
Fenny Septiyana ${ }^{1}$, Muchsin S. Shihab ${ }^{2}$, Hendra Kusumah ${ }^{3}$, Sugina $^{4}$, Dwi Apriliasari ${ }^{5}$ \\ ${ }^{1,2}$ Kawasan Rasuna Epicentrum, J1. H. R. Rasuna Said No.2, RT.2/RW.5, \\ Karet, Kecamatan Setiabudi, Kuningan, Daerah Khusus Ibukota Jakarta 12940. \\ ${ }^{3,4,5}$ University of Raharja Modern, J1. Jenderal Sudirman No.40, Cikokol, Kec. Tangerang, Kota \\ Tangerang, Banten 15117 \\ e-mail: admisi@bakrie.ac.id ${ }^{1}$, muchsin.shihab@bakrie.ac.id ${ }^{2}$, hendra.kusumah@raharja.info ${ }^{3}$, \\ sugina@raharja.info ${ }^{4}$,dwi.apriliasari@raharja.info ${ }^{5}$
}

\begin{tabular}{l} 
Article Info \\
Article history: \\
Received 14-12-2021 \\
Revised 29-12-2021 \\
Accepted 1-1-2023 \\
\hline
\end{tabular}

Keywords:

product quality

price perception social and culture value purchasing decision

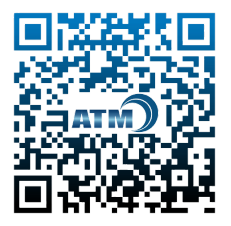

\begin{abstract}
PT)
Consumer purchasing decisions are an important factor in determining the existence of a product. Galeri Kalianda is a business engaged in the fashion sector providing tapis fabric, which is a woven fabric originating from the Lampung area. The purpose of this study was to determine the variable product quality (X1), perceived price (X2), and social and cultural values (X3) that influence the purchase decision of tapis lampung fabric (Y). The sampling technique used the Simple Random Sampling method with $(n=60)$ who had made purchases and users of the Lampung filter cloth at the Kalianda Gallery, Jakarta. Based on multiple linear regression analysis, the model $\mathrm{Y}=0.570+$ $0.136(\mathrm{x} 1)+0.299(\mathrm{x} 2)+0.223(\mathrm{x} 3)+\varepsilon$ is obtained. The $\mathrm{T}$ test shows that the variables of product quality, price perception, and social and cultural values partially have a positive and significant effect on purchasing decisions. While the $\mathrm{F}$ test shows that these three variables together have an effect of $(\mathrm{R} 2=$ $59.5 \%$ ) on purchasing decisions. The conclusions from the study entitled "The Influence of Product Quality, Price Perception and Social and Cultural Values on Purchase Decisions for Tapis Lampung Fabric (Case Study at Kalianda Gallery-Jakarta)" are: Product quality has a positive and significant influence on purchasing decisions for Lampung Tapis cloth at the Gallery. Kalinda-Jakarta. Price perception has a positive and significant influence on purchasing decisions for Lampung filter cloth at Kalianda Gallery, Jakarta.
\end{abstract}

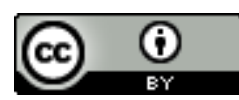

\section{Corresponding Author:}

Dwi Apriliasari

University of Raharja, Tangerang, Indonesia

Email: dwi.apriliasari@raharia.info

\section{INTRODUCTION}

Consumer purchasing decisions become an essential factor in determining the existence of a product. [1] A product can continue to exist if consumers decide to buy the product and get a positive response. Armstrong, the purchase decision is the buyer's decision- making process where the consumer makes a purchase. The researcher uses this purchasing decision variable because the study of purchasing decisions is still worthy of research considering the increasing number of products in circulation, resulting in the importance of various considerations for the public to make purchasing decisions.[2]

Consumers usually make consumer purchasing decisions after considering price, quality, and products already known by the wider community. This resulted in consumers actively seeking information first through various media and information sources to find out the product. After obtaining information and evaluating, consumers will buy a product that suits their wants and needs.[3] Before the decision is taken, a person will face 
a decision-making process consisting of problem recognition, information search, evaluation of alternatives, buying decisions, and post-purchase behavior.[4]

Factors that influence customer purchasing decisions are the emotional bonds between consumers and producers after consumers use products from the company and find that these products have added value. [5] Consumers also realize a difference between the actual condition and the desired condition. This causes consumer purchasing decisions for filter cloth to be determined by stimulating external factors such as product quality, price perceptions, and social and cultural values.

The first factor that influences purchasing decisions is product quality. Product quality is the ability of a product to perform its functions. A product can be said to be of high quality if the product can meet consumer desires. Good product quality is a consideration for consumers in making purchasing decisions. The second factor that influences purchasing decisions is price. Armstrong, price is the amount of money charged for a product. In decision-making, price is an essential consideration for consumers because consumers want the money they spend by what they receive. [6] In addition, factors that influence purchasing decisions are social and cultural values Sangadji \& Sopiah, as social beings in a particular environment, one's interaction with other people and their environment is a form of fulfilling one of their essential needs. Consumer purchasing decisions are influenced by social factors (interaction between consumers) and cultural factors (the way consumers live in their environment). So, the choice to buy does not always result in a rational purchase choice.[7]

The fashion industry is not only about the clothing industry as a basic human need. More broadly than that, fashion can describe a lifestyle in appearance and also reflects self or group identity. [8]The importance of the role of fashion is proven through its great contribution to the added value of the economy. In 2016, fashion ranked second and contributed to the GDP of Indonesia's Creative Economy (18.01\%).[9]

Kalinda Gallery is a business engaged in the fashion sector where it rents and sells various filter cloths along with bridal accessories and souvenirs typical of the Lampung region. Tapis cloth is one of the woven fabrics originating from the Lampung area and is a typical Indonesian tradition in which many cultural values have existed since ancient times. According to data from the Ministry of Education and Culture, filter cloth is one of the 77 artistic works that are designated as intangible cultural heritage. This Lampung tribal women's clothing is in the form of a sarong and made of woven cotton threads with motifs and decorations of embroidered silver or gold threads. [10]The motifs that are often used are usually flora and fauna motifs. The cloth tradition is rooted in the traditions of the Lampung people. Fabric making continues to use traditional tools and for months. It reflects the imagination and personality of the creator that appears in beautiful works.[11]

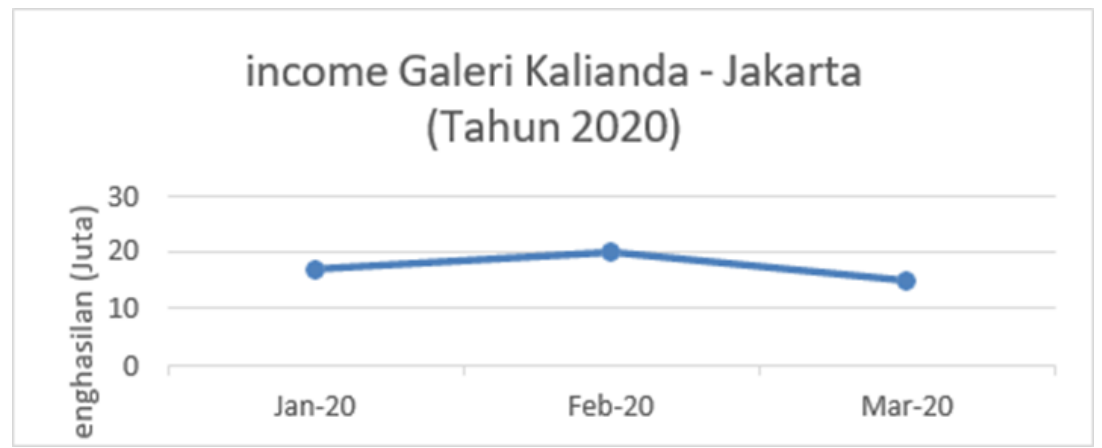

Figure 1. Graph of Kalianda-Jakarta Gallery Revenue (Year 2020)

\section{RESEARCH METHOD}

This type of research uses quantitative research methods. Research with a quantitative approach emphasizes testing theories by measuring variables with numbers and analyzing data using statistical procedures.

In this study, the sampling technique used is probability sampling, with the technique took being simple random sampling. Sugiyono, Simple random sampling is taking samples from the population at random without regard to the existing strata in the population. This method can be done if the population members are considered homogeneous. Thus, each sampling unit has the same opportunity to represent the population. This technique can also be used if the number of sampling units in a population is not too large.[12] 


\subsection{Formula/Algorithm}

Analysis of the data in this study using multiple linear regression analysis models. Multiple linear regression analysis was used to model the relationship between the dependent variable and the independent variable (more than one) or the variables that underlie consumer considerations in purchasing Lampung filter cloth. The data were processed using the SPSS 16.0 program.[13]

\subsection{Inter-Dimensional Correlation Test}

The correlation test between dimensions is used to determine the strength of the relationship between the correlation between independent and dependent dimensions, which is considered influential or controlled (as a control dimension). The dimension being examined is interval data, so the statistical technique used is Pearson Correlation Product Moment.[14]

From the data processing results, it can be seen the level of influence of the dimensions of the independent variable and the dimension of the dependent variable. The value of $r$ can vary from $-1<r<1$. As an interpretation of the correlation coefficient found to be large or small, it can be guided by the following provisions:

\begin{tabular}{c|c}
\hline $\begin{array}{c}\text { Interval } \\
\text { Koefisien }\end{array}$ & $\begin{array}{c}\text { Relationship } \\
\text { Level }\end{array}$ \\
\hline $0.00-0.199$ & Very low \\
\hline $0.20-0.399$ & Low \\
\hline $0.40-0.599$ & Currently \\
\hline $0.60-0.799$ & Strong \\
\hline $0.80-1.00$ & Very strong \\
\hline
\end{tabular}

Figure 2. Inter-Dimensional Correlation Test

\section{RESULTS}

Respondents used in this study are respondents who have purchased and are users of Lampung Tapis Fabric at Kalianda Gallery, Jakarta. Characteristics of respondents observed in this study include gender, age, occupation, and the number of purchase transactions made by respondents in the last six months. Explained that respondents with male sex as many as 12 people $(20 \%)$ and respondents with female sex as many as 48 people $(80 \%)$. Thus, this study was dominated by female respondents. For respondents aged $15-20$ years as many as one person (1.7\%), age $21-25$ years as many as five people (8.3\%), age $26-30$ years as many as six people $(10 \%)$, and age over 30 years as many as 48 people. $(80 \%)$.

Thus, this study was dominated by respondents aged over 30 years. For respondents with the employment status of civil servants as many as seven people (11.7\%), employment status of private employees as many as 22 people (36.7\%), employment status as self- employed as many as ten people (16.7\%), not working as many as $9(15 \%)$, and housewives stairs as much as $12(20 \%)$. Thus, this study was dominated by respondents with private employment status. For respondents with 34 people transaction one time (56.7\%), 12 people transaction two times $(20 \%)$, one person transaction three times $(1.7 \%)$, and the number of

transactions more than three times as many as 13 people $(21.7 \%)$. Thus, this research is dominated by respondents with the number of transactions one time.

\subsection{Discussion}

Based on the hypothesis testing in this study, it was found that all the hypotheses tested were accepted. The results of testing the first hypothesis (H1) show that product quality has a positive and significant effect on purchasing decisions for Lampung filter cloth at Kalianda Gallery, Jakarta.[15] It can be interpreted that the better the quality of the product, the better the purchase decision, so most people make purchasing decisions based on the quality of the products that Kalianda Gallery must fulfill. These results align with research conducted by Walukow that product quality influences purchasing decisions. In line with Cahya's opinion, goods must be able to meet the standards required by consumers, the excellent and impaired quality of the goods produced can also be seen from the consistency of meeting the expectations and needs of the community. [16] Based on the correlation between dimensions, it is known that the highest correlation is in the aesthetic dimension with product choice. This proves that the better the aesthetics (tidiness of the stitches, attractiveness 
of motifs, and variations in models) of Lampung tapis fabric, the customer's choice to buy filtered fabric will increase and increase purchasing decisions Lampung tapis fabric at Kalianda Gallery - Jakarta.[17]

The results of testing the second hypothesis (H2) prove that price perception has a positive and significant influence on purchasing decisions for Lampung filter cloth at Kalianda Gallery, Jakarta. [18]It can be interpreted that the higher the perception of the price, the purchasing decision will increase. These results indicate that the higher the price perception, the purchasing decision will increase. The results of this study are in line with the results of research conducted by Lomboan that price perception has a positive and significant influence on purchasing decisions. Based on the correlation results between dimensions, it is known that the highest correlation is in the dimension of price affordability with the choice of dealers. This proves that the affordable price of Lampung filter cloth will increase customers to buy Lampung filter cloth and have an impact on increasing purchasing decisions for Lampung filter cloth at Kalianda Gallery, Jakarta.[19]

The results of testing the third hypothesis (H3) indicate that social and cultural values positively and significantly influence purchasing decisions for Lampung filter cloth at Kalianda Gallery, Jakarta. It can be interpreted that the higher the social and cultural values, the higher the customer will be in making purchasing decisions, so most people make purchasing decisions based on the social and cultural values instilled by Kalinda Gallery. These results are in line with research conducted by Ginting that cultural factors have a positive and significant effect on purchasing decisions. Sari also found the same result that culture has an influence on purchasing decisions. According to Hidayati, cultural, sub- cultural, and social classes greatly influence consumer buying behavior. Society forms beliefs, values, and norms that describe most consumers' preferences. People absorb, almost unconsciously, a worldview that defines their relationships with themselves, other people, organizations, society, nature, and the universe. Based on the correlation between dimensions, it is known that the highest correlation is in the dimension of social class with product choice. This proves that if tapis cloth can reflect the social class of customers, it will increase the customer's choice to buy Lampung tapis cloth and will have an impact on increasing purchasing decisions for Lampung tapis cloth at Kalianda Gallery-Jakarta.[20]

Based on the results of simultaneous hypothesis testing (H4), the variables of product quality, price perception, and social and cultural values together have been shown to affect purchasing decisions. The variables of product quality, price perception, and social and cultural values together influence $59.6 \%$ on the purchasing decision of Lampung filter cloth at Kalianda Gallery-Jakarta. These results indicate that if product quality, price perception, and social and cultural values are improved together, purchasing decisions will increase. On the other hand, if the product quality, price perception, and social and cultural values are lower,

the purchasing decision will also decrease. [21] The results of this study support previous research conducted by Iryanita \& Sugiarto, which states that the perception of price and product quality has a significant positive effect on purchasing decisions. In line with research conducted by that, product quality, price perception, and social and cultural values simultaneously influence purchasing decisions.[22]

\section{CONCLUSION}

The conclusions from the study entitled "The Influence of Product Quality, Price Perception and Social and Cultural Values on Purchase Decisions for Tapis Lampung Fabric (Case Study at Kalianda Gallery-Jakarta)" are: Product quality has a positive and significant influence on purchasing decisions for Lampung Tapis cloth at the Gallery. Kalinda-Jakarta. Price perception has a positive and significant influence on purchasing decisions for Lampung filter cloth at Kalianda Gallery, Jakarta. Social and cultural values have a positive and significant influence on purchasing decisions for Lampung filter cloth at Kalianda Gallery-Jakarta. Product quality, price perception, and social and cultural values have a positive and significant influence on purchasing decisions for Lampung filter cloth at Kalianda Gallery, Jakarta.

\section{SUGGESTION}

The recommendations from the research entitled "The Influence of Product Quality, Price Perception and Social and Cultural Values on Lampung Tapis Fabric Purchase Decisions (Case Study at Kalianda Gallery-Jakarta)" are:

1. Share Kalianda Gallery

- For the Kalianda Gallery, they should pay more attention to the neatness of the stitches of Lampung filter cloth because it can increase customer choices for the quality of filter cloth at Kalianda Gallery.

- Kalianda Gallery must set a price so that it is affordable for consumers because it can increase customers who buy Lampung filter cloth at Kalianda Gallery.

- The Kalianda Gallery must also consider the social class of the customer because it can increase the number of customers who decide to purchase Lampung filter cloth at the Kalinda Gallery. 
2. For Further Researchers

This research provides space to examine the influence and how strong the relationship between product quality, price perception, and social and cultural values on customer satisfaction and repurchase intention. The results of the analysis of this study indicate that there is a significant influence between the variables of product quality, price perception, and social and cultural values on purchasing decisions for Lampung filter cloth at Kalianda Gallery.

\section{REFERENCES}

[1] M. H. Aminy, "Faktor-Faktor Yang Mempengaruhi Minat Pembeli Kain Tenun di Desa Sukarara Kecamatan Jonggat Kabupaten Lombok Tengah."

[2] I. Safitri, "The Influence of Product Price on Consumers' Purchasing Decisions," Rev. Integr. Bus. Econ. Res., vol. 7, pp. 328-337, 2018.

[3] M. F. Arfan, P. A. Fauzi, and E. S. Rini, "The Effect of Promotion, Price Perception and Product Quality on Purchasing Weaving Decisions on Consumers of Raki Weaving Assisted by Deli Serdang Cooperative Service," IJJR_International J. Res. Rev., vol. 6, no. July, pp. 349-360, 2019, [Online]. Available: http://ijrrjournal.org/IJRR_Vol.6_Issue.7_July2019/IJRR0043.pdf.

[4] Y. Y. Anggoro and H. D. Waluyo, "Pengaruh Store Atmosphere, Desain Produk dan Harga Terhadap Keputusan Pembelian di Larissa Gallery \& Workshop Pekalongan," J. Ilmu Adm. Bisnis, vol. 6, no. 3, pp. 309-317, 2017.

[5] P. I. Parnanda, H. Santosa, and I. Wibisono, "Perubahan Pola Ruang Dalam Pada Home Industry Sarung Tenun Samarinda di Kecamatan Samarinda Seberang,” J. Mhs. Jur. Arsit., vol. 5, no. 1, 2017.

[6] A. K. Badri, J. Heikal, Y. A. Terah, and D. R. Nurjaman, "Decision-Making Techniques using LSTM on Antam Mining Shares before and during the COVID-19 Pandemic in Indonesia," APTISI Trans. Manag., vol. 6, no. 2, pp. 167-180, 2022.

[7] S. H. Jassim and R. K. H. Shubar, "Sustainable Marketing Analysis in Industrial Corporate: a Case Study At the General Company for Iraqi Cement," PalArch's J. Archaeol. Egypt/Egyptology, vol. 17, no. 3, pp. $2375-2395,2020$.

[8] M. Ginting and H. Sembiring, "The Effect of Product Innovation, Product Quality And City Image on Purchase Decision of Uis Karo Woven Fabric," vol. 46, no. Ebic 2017, pp. 593-598, 2018, doi: 10.2991/ebic-17.2018.94.

[9] L. Gallery and W. Pekalongan, "Pengaruh Store Atmosphere, Desain Produk dan Harga Terhadap Keputusan Pembelian di Larissa Gallery \& Workshop Pekalongan Yanuar Yoga Anggoro1 \& Handojo Djoko Waluyo2 1 Yanuar Yoga Anggoro ., Administrasi Bisnis, Fakultas Ilmu Sosial dan Ilmu Politik, U.”

[10] S. Kasus and K. Manado, "Analysis the Influence of Perceived Quality, Perceived Price and Perceived Value on Consumer Purchase Intention in Traditional Fabrics (Case Study Kaeng Manado)," J. Berk. Ilm. Efisiensi, vol. 17, no. 01, pp. 100-112, 2017.

[11] S. Jun, S. Yoyok, Sanaji, and W. S. Chendra, "Antecedents of Consumer Buying Intention on the Products of Hijab SMEs in Gresik," HOLISTICA - J. Bus. Public Adm., vol. 11, no. 1, pp. 1-12, 2020, doi: 10.2478/hjbpa-2020-0001.

[12] H. Saputra, "Seni dan budaya tenun ikat Nusantara," Res. Gate, vol. 1, no. May, pp. 1- 15,2019, [Online].Available:https://www.researchgate.net/publication/333338833_Seni_dan_Budaya_Tenun_Ikat_N usantara.

[13] S. Taufiq, "ANALISIS PENGARUH KUALITAS PRODUK DAN BRAND AWARENESS TERHADAP KEPUTUSAN PEMBELIAN PRODUK ( Studi Kasus Pada Konsumen Produk Batik Merek The Bluesville )," Anal. Pengaruh Kualitas Prod. Dan Brand Aware. Terhadap Keputusan Pembelian Prod. Batik Nat. Indigo Dye., vol. 6, no. 3, p. 12, 2014. 
[14] S. Widyastutir and M. Said, "Consumer consideration in purchase decision of SPECS sports shoes product through brand image, product design and price perception,” Int. J. Supply Chain Manag., vol. 6, no. 4, pp. 199-207, 2017.

[15] K. Arora and A. S. Bist, "Artificial intelligence based drug discovery techniques for covid- 19 detection," Aptisi Trans. Technopreneursh., vol. 2, no. 2, pp. 120-126, 2020.

[16] A. S. Bein, Y. I. Graha, and A. P. Pangestu, "Pandawan Website Design Based Content Management System As Media E-commerce Transaction,” Aptisi Trans. Technopreneursh., vol. 2, no. 1, pp. 87-97, 2020.

[17] U. Rahardja, A. N. Hidayanto, P. O. H. Putra, and M. Hardini, "Immutable Ubiquitous Digital Certificate Authentication Using Blockchain Protocol,” J. Appl. Res. Technol., vol. 19, no. 4, pp. 308-321, 2021.

[18] A. S. Anwar, U. Rahardja, A. G. Prawiyogi, and N. P. L. Santoso, "iLearning Model Approach in Creating Blockchain Based Higher Education Trust,” Int. J. Artif. Intell. Res., vol. 6, no. 1, 2022.

[19] U. Rahardja, A. N. Hidayanto, N. Lutfiani, D. A. Febiani, and Q. Aini, "Immutability of Distributed Hash Model on Blockchain Node Storage,” Sci. J. Informatics, vol. 8, no. 1, pp. 137-143, 2021.

[20] D. Apriani, A. Williams, U. Rahardja, A. Khoirunisa, and S. Avionita, "The Use of Science Technology In Islamic Practices and Rules In The Past Now and The Future,” Int. J. Cyber IT Serv. Manag., vol. 1, no. 1, pp. 48-64, 2021.

[21] W. Setyowati, P. C. Kurniawan, A. Mardiansyah, E. P. Harahap, and N. Lutfiani, "The Role Of Duty Complexity As A Moderation Of The Influence Auditor's Professional Knowledge And Ethics On Audit Quality,” Aptisi Trans. Manag., vol. 5, no. 1, pp. 20-29, 2021.

[22] Q. Aini, E. P. Harahap, and F. Faradilla, "The Effects of Sales Reports Business Intelligence on Employee Performance," Aptisi Trans. Manag., vol. 4, no. 1, pp. 83-91, 2020. 